\title{
Chest wall metastasis in squamous cell carcinoma of buccal mucosa
}

\author{
Jayesh Shyamnandan Singh, Ashutosh Das Sharma \\ Gujarat Cancer and Research Institute, Radiotherapy Room 54 Civil Hospital Campus Asarawa, Ahmedabad, Gurarat 380016, India.
}

Correspondence to: Dr. Jayesh Shyamnandan Singh, Gujarat Cancer and Research Institute, Radiotherapy Room 54 Civil Hospital Campus Asarawa, Ahmedabad, Gurarat 380016, India. E-mail: dr.singh3788@yahoo.com

How to cite this article: Singh JS, Sharma AD. Chest wall metastasis in squamous cell carcinoma of buccal mucosa. J Cancer Metastasis Treat 2017;3:78-81.

\section{Article history: \\ Received: 23-01-2017 \\ Accepted: 07-03-2017 \\ Published: 28-04-2017}

\section{Key words:}

Head and neck,

squamous cell carcinoma,

chest wall,

metastasis

\begin{abstract}
Metastases from head and neck cancers is rare occurrence. The common form of failure/ recurrence in these cancers are local site recurrence or nodal metastases. Distant metastases are very rare and are most commonly seen in the lung, brain, liver and bones, and the latent period between the development of the primary and the distant metastases is usually long. There are very few cases reported of chest wall metastases from squamous cell carcinoma of head and neck. This article reports such a case of squamous cell carcinoma of buccal mucosa metastasizing to the chest wall four months after primary therapy. The metastasis was treated with local palliative radiotherapy to the chest wall. This case is special as the present knowledge on this type of presentation is limited in the medical literature.
\end{abstract}

\section{INTRODUCTION}

Head and neck malignancy is a major burden of cancer worldwide being the sixth most common malignancy. ${ }^{[1]}$ It is the most common cancer in developing countries and its incidence shows an increasing trend. ${ }^{[2]}$ In southeast Asia region, the oral cavity is the most prevalent site of head and neck squamous cell carcinoma. ${ }^{[3]}$ Widespread use of smokeless tobacco products such as pan and supari in this population is the major cause of this high incidence. ${ }^{[4]}$ Advancement in the treatment of primary head and neck cancers has resulted in improvement of loco-regional control as well increased disease free survival and overall survival of this subgroup of patients. ${ }^{[5]}$ Though distant metastasis are considered uncommon sites of failure for primary head and neck cancer, increased survival has resulted in an apparent increase in distant metastasis. The incidence of distant metastasis in patient of squamous cell carcinoma of oral cavity is low, i.e. approximately $15 \%$ to $20 \%$ of patients. ${ }^{[6,7]}$ Most common sites for distant metastasis in these cases are lung, liver, bone, thyroid. ${ }^{[8]}$ But distant metastasis to sites other than these, such as kidney, diaphragm, heart, brain, adrenal, thyroid pancreas and peritoneum are uncommon. ${ }^{\left[{ }^{9]}\right.}$ The risk of distant metastasis increases with the increase in number of histologically positive lymph nodes and with the presence of extranodal spread. ${ }^{[10]}$ We report such

c) (i) (2) This is an open access article distributed under the terms of the Creative Commons AttributionEY NC SA NonCommercial-ShareAlike 3.0 License, which allows others to remix, tweak, and build upon the work non-commercially, as long as the author is credited and the new creations are licensed under the identical terms.

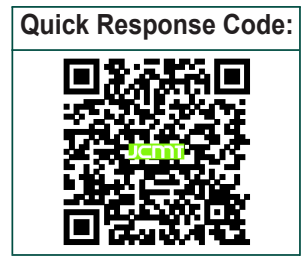


an unusual case of squamous cell carcinoma of buccal mucosa that presented with distant metastasis to the chest wall.

\section{CASE REPORT}

A 20-year-old gentleman presented with an ulcer on the right cheek. The lesion was of 2-3 months duration. There was associated swelling on the right side of the neck region. He gave a history of tobacco chewing in the form of gutkha (a mixture of tobacco, betel nut, and lime) since last 7-8 years. A punch biopsy from the ulcer and subsequent histopathological examination of the biopsy sample confirmed the diagnosis of squamous cell carcinoma of buccal mucosa. The patient underwent wide local excision surgery of the primary lesion with right sided modified radical neck dissection in May 2016. Surgical pathology report was suggestive of a pathological staging $\mathrm{pT}_{1} \mathrm{~N}_{2} \mathrm{bM}_{0}$ with lymphovascular invasion and perinodal extension. The patient was advised adjuvant post-operative radiotherapy with concurrent chemotherapy (cisplatin weekly at $40 \mathrm{mg} / \mathrm{m}^{2}$ ). He received $60 \mathrm{~Gy}$ by external beam radiotherapy in 30 fractions by conventional twodimensional planning on a $6 \mathrm{MV}$ linear accelerator with five cycles of concurrent cisplatin. Adjuvant therapy was concluded in August 2016. The patient was kept on follow-up, during which he was free of any symptoms and signs of the disease. After a diseasefree survival of 4 months, he presented with swelling and redness over the right side of the chest wall in December 2016. On examination, the swelling was an indurated, erythematous, tender, hard, fixed mass of $7 \mathrm{~cm} \times 7 \mathrm{~cm}$ in the right upper chest wall away from the pectoral flap site [Figure 1]. A computed tomography scan of the neck, paranasal sinuses and thorax was suggestive of soft tissue opacity in the right upper chest wall and right axillary region [Figure 2]. There was also a recurrent lesion present involving the superior aspect of the flap in right retro-antral fat space in the oral cavity [Figure 3]. Fine needle aspiration cytology examination from the chest wall mass was suggestive of metastatic squamous cell carcinoma. Biopsy from the oral lesion confirmed recurrent squamous cell carcinoma [Figure 4]. No other lesion was present anywhere else in the body either by clinical examination or radiological investigations. The patient was advised palliative radiotherapy (30 Gy in 10 fractions) in view of unresectable disease and was treated with a conventional anteroposterior field on a telecobalt machine along with aspiration and drainage of the axillary collection. The patient was referred to palliative medicine for supportive care. He was lost to follow-up after January 2017.

\section{DISCUSSION}

Distant metastases from head and neck cancer are unusual. The commonest site is lungs, bones, and liver and usually, occur after a long latent period. ${ }^{[9]}$ The risk of incidence of distant metastasis depends on the age of patient, site of the primary cancer, locoregional extension, tumor grade, and loco-regional control by primary treatment. ${ }^{[11]}$ The risk of developing distant metastasis in head and neck cancer increases with the development of regional metastasis and is associated with poor survival..[12] Metastases to chest wall from head and neck cancer are extremely rare, with only a few cases reported in the literature till date. Metastasis to such an unusual sites may be due to the disruption of lymphatic system during surgery which resulted in the lymphatic dissemination of malignant cells to the region below the clavicle. ${ }^{[13]}$ Here recurrence at the pectoralis flap site due to

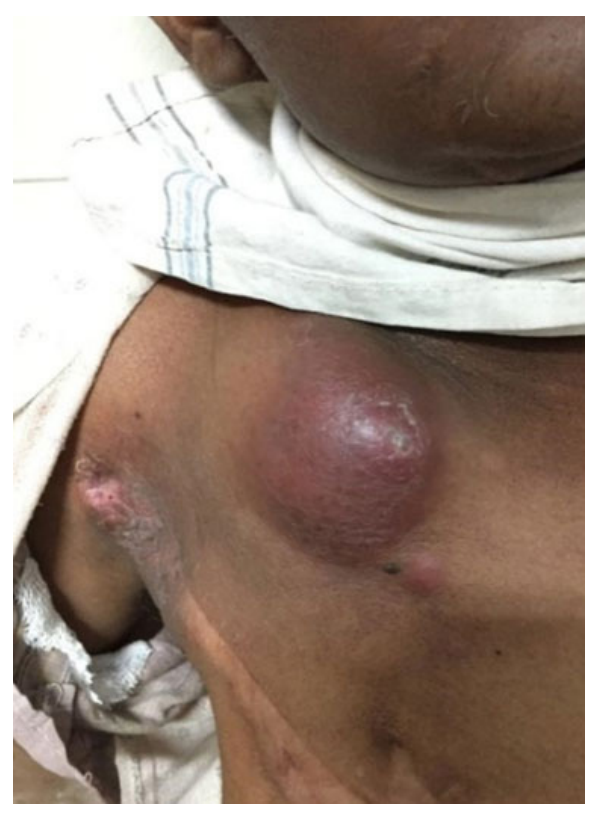

Figure 1: Clinical photograph of the chest wall lesion

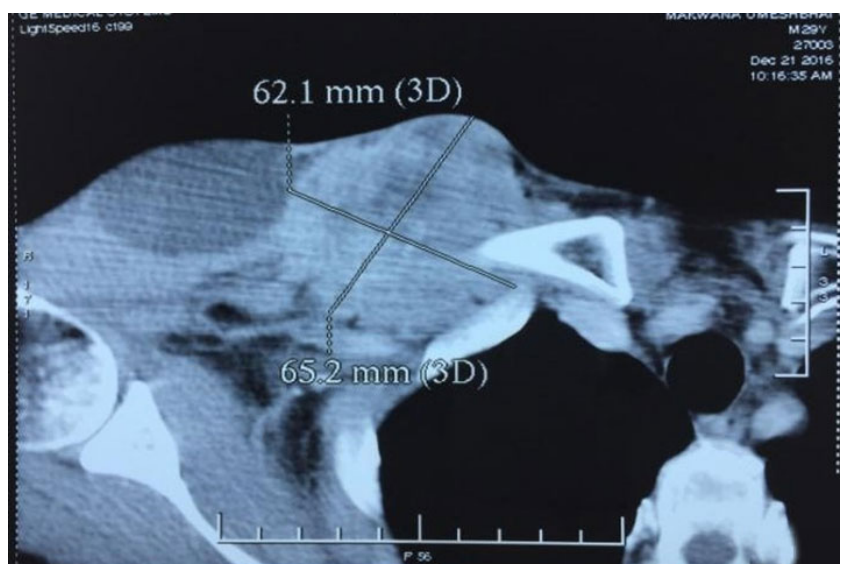

Figure 2: Computed tomography of thorax showing the chest wal lesion 


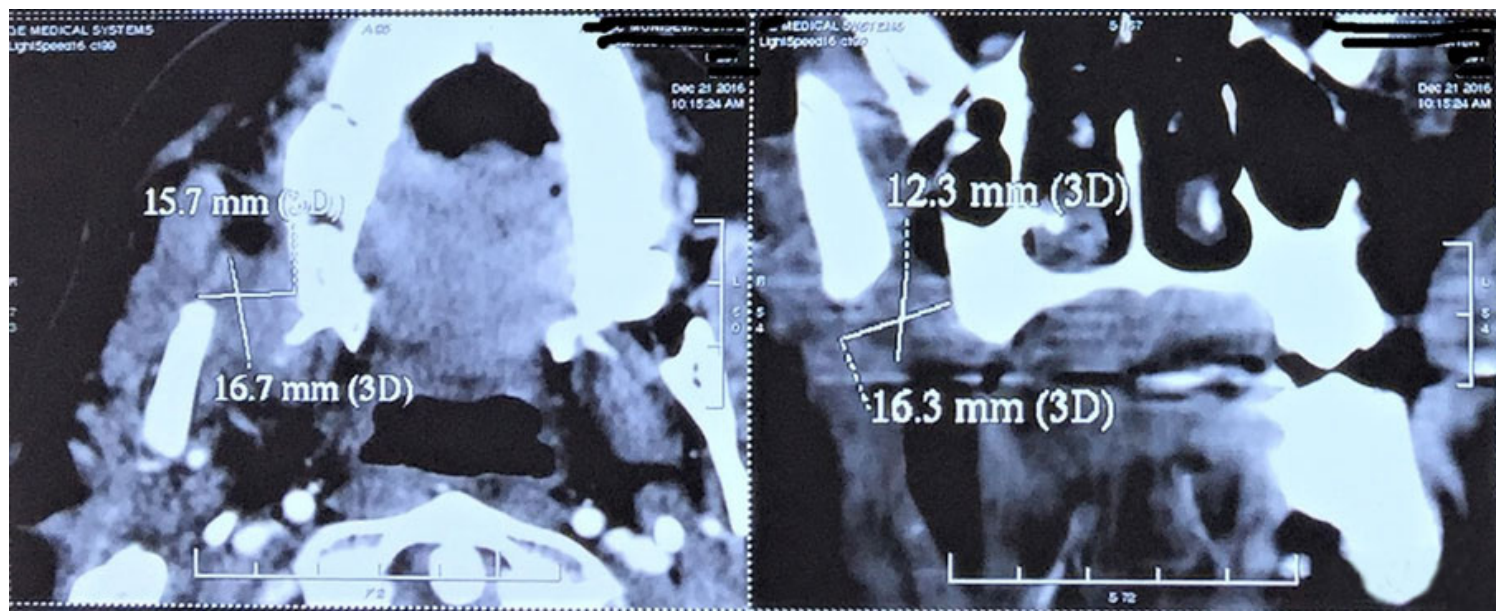

Figure 3: Computed tomography showing the local recurrent lesion at the flap site

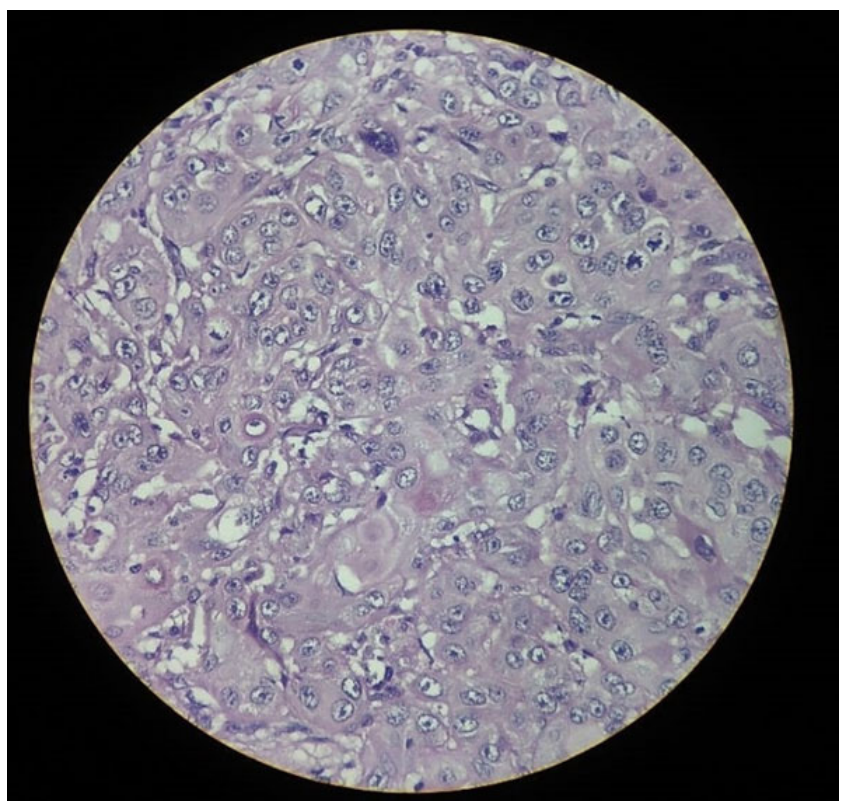

Figure 4: Histopathology slide showing malignant squamous cell $(\mathrm{HE}, \times 40)$

surgical dissemination of primary tumor cell can be safely ruled out as the site of distant metastasis is not continuous with the surgical bed. Hematogenous spread can be another explanation for these rare recurrences. ${ }^{[14]}$ In literature, kidney, diaphragm, heart, brain, adrenal, thyroid, pancreas and peritoneum have been mentioned as rather rare sites of metastasis in head and neck squamous cell carcinoma. ${ }^{\left[{ }^{[]}\right.}$The prognosis of these cases remain poor and the intention of therapy is usually palliative with either excision, palliative local radiotherapy or palliative chemotherapy for widespread systemic metastasis. ${ }^{[15]}$ After thorough search of literature, we couldn't find a case report on buccal mucosa presenting with chest wall metastasis which makes this case extremely rare.

In conclusion, chest wall metastasis from squamous cell carcinoma of buccal mucosa is a rare occurrence with no reported case in published literature. The present knowledge on this topic is very limited and this case report is intended to add to the existing information. This will help in better management of the patients who present with this rare incidence.

\section{Authors' contributions}

Concept, manuscript development and literature search: J.S. Singh, A.D. Sharma

\section{Financial support and sponsorship None.}

\section{Conflicts of interest}

There are no conflicts of interest.

\section{Patient consent}

Patient consent was acquired.

\section{Ethics approval}

The study has been approved.

\section{REFERENCES}

1. Parkin DM, Stjernswärd J, Muir CS. Estimates of the worldwide frequency of twelve major cancers. Bull World Health Organ 1984;62:163-82

2. Mishra A, Meherotra R. Head and neck cancer: global burden and regional trends in India. Asian Pac J Cancer Prev 2014;15:537-50.

3. Bhurgri Y, Bhurgri A, Usman A, Pervez S, Kayani N, Bashir I, Ahmed R, Hasan SH. Epidemiological review of head and neck cancers in Karachi. Asian Pac J Cancer Prev 2006;7:195-200.

4. Dayal PK, Mani NJ, Bhargava K. Prevalence of oral cancer and precancerous lesions in 'pan'/'supari' chewers. Indian J Public Health 1978;22:234-45

5. Genden EM, Ferlito A, Bradley PJ, Rinaldo A, Scully C. Neck disease and distant metastases. Oral Oncol 2003;39:207-12.

6. Edward CH, Luther WB, Carlos AP, David EW. Perez and Brady's principles and practice of radiation oncology, 6th ed. Philadelphia: Lippincott-Raven; 2013 
7. Lin CS, Jen YM, Cheng MF, Lin YS, Su WF, Hwang JM, Chang LP, Chao HL, Liu DW, Lin HY, Shum WY. Squamous cell carcinoma of the buccal mucosa: an aggressive cancer requiring multimodality treatment. Head Neck 2006;28:150-7.

8. Ferlito A, Shaha AR, Silver CE, Rinaldo A, Mondin V. Incidence and sites of distant metastases from head and neck cancer. $O R L J$ Otorhinolaryngol Relat Spec 2001;63:202-7.

9. Zbären P, Lehmann W. Frequency and sites of distant metastases in head and neck squamous cell carcinoma. An analysis of 101 cases at autopsy. Arch Otolaryngol Head Neck Surg 1987;113:762-4.

10. Leemans CR, Tiwari R, Nauta JJ, van der Waal I, Snow GB. Regional lymph node involvement and its significance in the development of distant metastases in head and neck carcinoma. Cancer 1993;71:452-6.

11. Garavello W, Ciardo A, Spreafico R, Gaini RM. Risk factors for distant metastases in head and neck squamous cell carcinoma. Arch
Otolaryngol Head Neck Surg 2006;132:762-6.

12. Spector JG, Sessions DG, Haughey BH, Chao KS, Simpson J, El Mofty S, Perez CA. Delayed regional metastases, distant metastases, and second primary malignancies in squamous cell carcinomas of the larynx and hypopharynx. Laryngoscope 2001;111:1079-87.

13. Alavi S, Namazie A, Sercarz JA, Wang MB, Blackwell KE. Distant lymphatic metastasis from head and neck cancer. Ann Otol Rhinol Laryngol 1999;108:860-3.

14. Yucel EA, Demirel T, Demiryont M, Egeli U, Deger K. An unusual metastatic site of laryngeal carcinoma: scapular muscles. J Laryngol Otol 2003;117:85-7.

15. Cole RD, McGuirt WF. Prognostic significance of skin involvement from mucosal tumors of the head and neck. Arch Otolaryngol Head Neck Surg 1995;121:1246-8. 